Dubo, H., Park, D. C., Pennington, R. J. T., Kalbag, R. M., and Walton, J. N. (1967). Lancet, 2, 743.

Elliot, B. A., and Wilkinson, J. H. (1961). Lancet, 1, 698.

Heikkilä, J., Luomanmäki, K., and Pyörälä, K. (1971). Acta Medica Scandinavica, 190, 89.

Konttinen, A., Hupli, V., Louhija, A., and Härtel, G. (1969). New England Fournal of Medicine, 281, 231.

Konttinen, A., Härtel, G., and Louhija, A. (1970). Acta Medica Scandinavica, $188,257$.

Konttinen, A., and Somer, H. (1972). American fournal of Cardiology, 29, 817.

Pearce, J. M. S., Pennington, R. J., and Waltor, J. N. (1964). Fournal of Neurology, Neurosurgery and Psychiatry, 27, 96.
Perkoff, G. T. (1968). Archives of Internal Medicine, 122, 326.

Perloff, J. (1964). Circulation, 30, 706.

Reichard, H. (1960). Fournal of Laboratory and Clinical Medicine, 56, 218

Smith, A. F. (1967). Lancet, 2, 178.

Somer, H., and Konttinen, A.' (1972a). Clinica Chimica Acta, 36, 531.

Somer, H., and Konttinen, A. (1972a). Clinica Chimica Acta, 36, 531.

Takahashi, K., Ushikubo, S., Oimomi, M., and Shinko, T. (1972). Clinica Chimica Acta, 38, 285.

Van der Veen, K. J., and Willebrands, A. F. (1966). Clinica Chimica Acta, 13, 312 .

Wieme, R. J., and Herpol, J. E. (1962). Nature, 194, 288.

Wróblewski, F., and Gregory, K. F. (1961). Annals of the New York Academy of Sciences, 94, 912 .

\title{
Primary Acquired Sideroblastic Anaemia: Response to Treatment with Pyridoxal-5-Phosphate
}

\author{
D. Y. MASON, PAULINE M. EMERSON
}

British Medical fournal, 1973, 1, 389-390

\section{Summary}

A 72-year-old woman with primary sideroblastic anaemia showed no response to treatment with pyridoxine. When she was given pyridoxal-5-phosphate there was a prompt reticulocyte response and sustained symptomatic improvement with satisfactory control of the anaemia.

\section{Introduction}

Primary acquired sideroblastic anaemia is a well-defined form of anaemia characterized by a heavy perinuclear infiltrate of iron-containing granules in the developing marrow normoblasts. These "ring" sideroblasts are thought to represent an unidentified defect in haem synthesis (Bessis and Jensen, 1965; Bousser et al., 1967), which for some reason usually manifests itself only in the later decades of life (Macgibbon and Mollin, 1965). In contrast to the secondary type of sideroblastic anaemia no associated diseases or drug ingestion can be identified.

Pyridoxine is a necessary coenzyme for haem synthesis (Kikuchi et al., 1958; Levere and Granick, 1965), and the possibility that a defect in its metabolism is responsible for sideroblastic erythropoiesis finds support in the appearance of atypical sideroblasts in pyridoxine-deficient animals (Harriss et al., 1965) and in patients receiving pyridoxine antagonists such as cycloserine or isoniazid (Verwilghen et al., 1965). Furthermore, treatment with oral pyridoxine may lead to haematological improvement in cases of sideroblastic anaemia. However, response to pyridoxine is almost always suboptimal and occurs in only $40-50 \%$ of patients (Macgibbon and Mollin, 1965). In addition very large doses of the drug, often 100 times the normal nutritional requirement, may be necessary.

For these reasons it has been suggested that a block in the conversion of pyridoxine to its main active form, pyridoxal5-phosphate, is the underlying cause of sideroblastic anaemia (Hines and Grasso, 1970). This conversion, which can occur within the red cell (Anderson et al., 1971), has been shown to be defective both in alcohol-induced and primary sideroblastic anaemia (Hines and Cowan, 1970; Hines and Love, 1969).

Department of Haematology, Radcliffe Infirmary, Oxford D. Y. MASON, B.M., B.CH., Lecturer in Haematology

PAULINE M. EMERSON, M.D., M.R.C.PATH., Consultant Haematologist
A direct corollary of this hypothesis is that pyridoxal5-phosphate should prove therapeutically much more effective than pyridoxine in sideroblastic anaemia. The present report is of a case of primary acquired sideroblastic anaemia which was unresponsive to prolonged treatment with pyridoxine but which responded dramatically to pyridoxal-5-phosphate.

\section{Clinical History}

The patient was admitted to the Radcliffe Infirmary in July 1968, aged 72 , with a nine-month history of dyspnoea, ankle oedema, and lassitude. Apart from rheumatic fever as a child she had enjoyed good health, having been a regular blood donor until 1960. On examination she was pale and in congestive cardiac failure with evidence of mitral and aortic valve incompetence. The haemoglobin was $4.8 \mathrm{~g} / 100 \mathrm{ml}$ and the peripheral blood film showed a double population of hypochromic and normochronic erythrocytes, together with numerous poikilocytes and occasional nucleated red cells. Bone marrow aspiration showed erythroid hyperplasia with a disproportionate increase in early red cell precursors. Most of the later forms were shown to be ring sideroblasts on Perl's staining. These cells were negative on P.A.S. staining and marrow chromosome preparations were normal.

Results of biochemical tests were normal except for a serum bilirubin of $1.0 \mathrm{mg} / 100 \mathrm{ml}$ and a plasma lactic dehydrogenase of 300 $\mathrm{mU} / \mathrm{ml}$. The plasma iron was $150 \mu \mathrm{g} / 100 \mathrm{ml}$, with a saturation of $48 \%$. Ferrokinetic studies with ${ }^{50} \mathrm{Fe}$ showed an increased plasma clearance $\left(\mathrm{t} \frac{1}{2} 12 \mathrm{~min}\right.$.) and a reduced red cell utilization ( $22 \%$ on day 14$)$. Careful investigation failed to produce evidence of any other disease.

After transfusion and conventional therapy for congestive failure treatment was started with oral folate $(5 \mathrm{mg}$ three times a day) to which was later added pyridoxine ( $100 \mathrm{mg}$ twice daily) and ascorbic acid (200 mg twice daily). Each drug was given continuously for several months without any evidence of haematological response (see chart). Further transfusions were given in September and December 1968 but by February 1969 the haemoglobin had fallen to 7.0 $\mathrm{g} / 100 \mathrm{ml}$. At this stage, because of a transient reticulocytosis which had been noted during her first admission following a tryptophan loading test (see chart), she began taking oral tryptophan at an initial dose of $2 \mathrm{~g}$ daily, later increased to $\mathbf{4 g}$ daily, in addition to the other haematinics. Although this new treatment appeared to cause a reticulocytosis and an increase in haemoglobin, the improvement was transient. She developed diarrhoea, and in May, after a total consumption of $280 \mathrm{~g}$ of tryptophan, all treatment for anaemia was stopped.

After a further transfusion she maintained a haemoglobin level of $7.5 \mathrm{~g} / 100 \mathrm{ml}$ until November 1969 . She then required increasingly frequent blood transfusions because of recurrent episodes of cardiac failure. Although desferrioxamine treatment had been initiated in November 1968, and was given at the time of each transfusion, a bone marrow specimen in March 1971 showed an increase in storage iron, and a serum iron of $215 \mu \mathrm{g} / 100 \mathrm{ml}$ with $75 \%$ saturation was recorded. By this time she had received a total of 62 units of blood since the diagnosis. In addition the transfusions had been complicated by the 


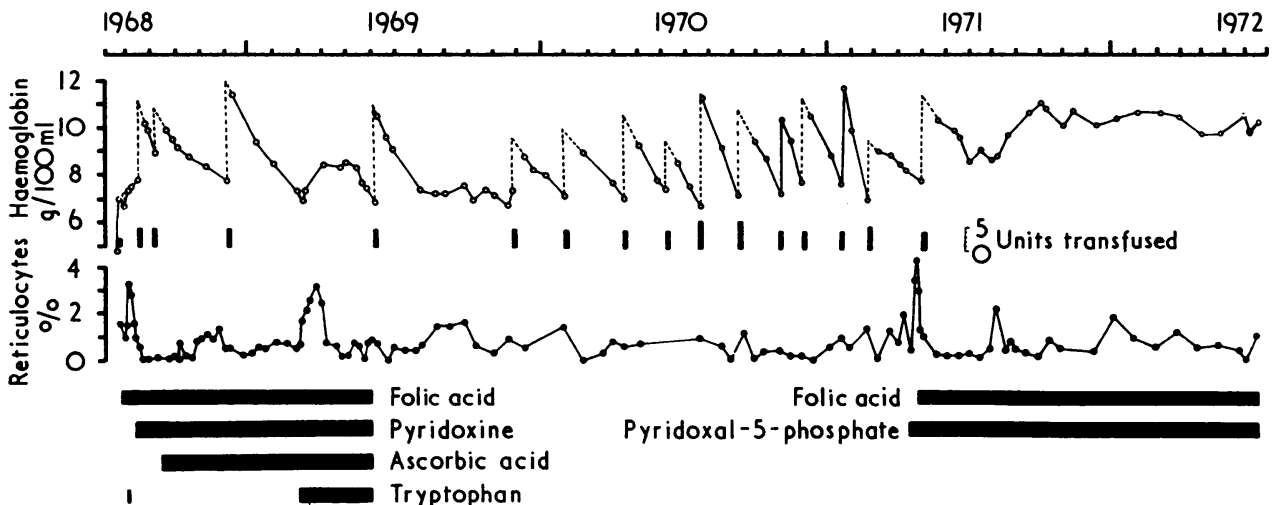

Haematological progress and treatment. appearance of an anti-Kell antibody in June 1969 and increasingly severe allergic reactions necessitating transfusion with dextran sedimented blood and chlorpheniramine cover.

Treatment with intramuscular pyridoxal-5-phosphate* was started in April 1971 at an initial dosage of $250 \mathrm{mg}$ daily, later reduced to $250 \mathrm{mg}$ weekly when a maximal haemoglobin response had been obtained.

A prompt reticulocyte response was noted with a peak of $4.5 \%$ on day 10, and after five months of treatment the haemoglobin had risen to $11.0 \mathrm{~g} / 100 \mathrm{ml}$. From October 1971 until the time of writing a constant haemoglobin was maintained between 10 and $11 \mathrm{~g} / 100$ $\mathrm{ml}$ without further transfusion and the patient had remained well. Ferrokinetic studies repeated in November 1971 after six months' therapy still showed increased iron clearance $\left(t \frac{1}{2} 23 \mathrm{~min}\right.$ ) and poor iron utilization (22\% at 14 days). Bone marrow aspirations at this time and in July 1972, after 14 months of treatment, still showed the persistence of numerous ring sideroblasts.

\section{Discussion}

This case is a typical example of primary acquired sideroblastic anaemia. No evidence of any other disorder was found; in particular the P.A.S.-negative marrow erythroid precursors (Hayhoe and Quaglino, 1960), the normal marrow chromosome pattern (Heath et al., 1969), and the constancy of the sideroblastic abnormality over the course of four years all argue against an underlying leukaemic process.

Pyridoxal phosphate is necessary for the activation of glycine in the initial stages of haem production. Theoretically, therefore, a deficiency or inhibition of the phosphorylatiag enzyme (pyridoxal kinase) required for the conversion of pyridoxine to its active form (pyridoxal-5-phosphate) could lead to disordered haem synthesis and accumulation of iron within the mitochondria. However, the fact that there was no evidence from marrow aspiration or ferrokinetic studies that treatment had reversed the sideroblastosis suggests that additional factors other than defective pyridoxal phosphate synthesis underlay the abnormality.

From a therapeutic point of view, however, the present findings suggest that pyridoxal-5-phosphate should be tried in all cases of symptomatic primary sideroblastic anaemia which have shown no satisfactory response to pyridoxine. There is very little published information on the therapeutic value of pyridoxal-5-phosphate to date. Gehrmann (1965) described the case of a 31-year-old man with acquired sideroblastic anaemia who responded rather better to small doses of pyridoxal-5-phosphate ( $25 \mathrm{mg} /$ day) than to much larger doses of pyridoxine (300 mg/day). Hines and Grasso (1970) referred to *By courtesy of Roche Products, Welwyn Garden City, Herts. a patient who showed a prompt reticulocytosis when given pyridoxal-5-phosphate $(20 \mathrm{mg} /$ day $)$, having been previously unresponsive to pyridoxine (100 mg/day). We could find no other reports of therapy with pyridoxal-5-phosphate in primary sideroblastic anaemia; undoubtedly the paucity of information stems in part from the fact that the drug has yet to be approved for general use in either the U.K. or the United States. We found no evidence, in the course of more than a year's treatment, of toxicity or side effects to contraindicate its use.

Finally, it should be pointed out that pyridoxal phosphate is given parenterally, whereas pyridoxine, being well absorbed from the gastrointestinal tract, is usually given by the oral route, as it was in this patient. It is therefore conceivable that in this case the failure to respond to pyridoxine, although the dose was about three times the maintenance dose of pyridoxal phosphate, was due to intestinal malabsorption. There was no evidence, however, of a malabsorption syndrome, and adequate absorption of at least one other drug, folic acid, was implied by high serum levels achieved. In addition direct evidence that resistance to pyridoxine in sideroblastic subjects may not be related to poor absorption is found in Hines and Cowan's (1970) observation that patients with alcohol-induced sideroblastic anaemia responded to intramuscular pyridoxal phosphate but not to intravenous pyridoxine.

We should like to thank Dr. J. Badenoch for allowing us to report this case.

\section{References}

Anderson, B. B., Fulford-Jones, C. F., Child, A. J., Beard, M. E. J., and Bateman, C. J. T. (1971). Fournal of Clinical Investigation, 50, 1901.

Bessis, M. C., and Jensen, W. N. (1965). British fournal of Haematology,

11, 49.
Bousser, J., Gajdos, A., Gajdos-Török, M., Bilski-Pasquier, G., and Zittoun, R. (1967). Nouvelle Revue Française d'Hématologie, 7, 847.

Gehrmann, G. (1965). British fournal of Haematology, 11, 86.

Harriss, E. B., Macgibbon, B. H., and Mollin, D. L. (1965). British fournal of Haematology, 11, 99 .

Hayhoe, F. G. J., and Quaglino, D. (1960). British fournal of Haematology, 6, 381 .

Heath, C. W., jun., Bennett, J. M., Whang-Peng, J., Berry, E. W., and

Wiernick, P. H. (1969). Blood, 33, 453 .
Hines, J. D., and Cowan, D. H. (1970). New England fournal of Medicine, 283, 441 .

Hines, J. D., and Grasso, J. A. (1970). Seminars in Haematology, 7, 86.

Hines, J. D., and Love, D. S. (1969). Fournal of Laboratory and Clinical Medicine, 73, 343.

Kikuchi, G., Kumar, A., Talmage, P., and Shemin, D. (1958). Fournal of Biological Chemistry, 233, 1214.

Levere, R. D., and Granick, S. (1965). Proceedings of the National Academy of Sciences, 54, 134.

Macgibbon, B. H., and Mollin, D. L. (1965). British fournal of Haematology, 11,59 .

Verwilghen, R., Reybrouck, G., Callens, L., and Cosemans, J. (1965). British fournal of Haematology, 11, 92. 